\title{
Technopolitics from Below: A Framework for the Analysis of Digital Politics of Production
}

\author{
Simon Schaupp (D)
}

Received: 11 March 2020 / Accepted: 4 February 2021 / Published online: 23 April 2021

(C) The Author(s) 2021

\begin{abstract}
This article develops a multi-level framework for the analysis of a bottom-up politics of technology at the workplace. It draws on a multi-case study on algorithmic management of manual labor in manufacturing and delivery platforms in Germany. In researching how workers influenced the use of algorithmic management systems, the concept of technopolitics is developed to refer to three different arenas of negotiation: (1) the arena of regulation, where institutional framings of technologies in production are negotiated, typically between state actors, employers' associations, and unions. (2) The arena of implementation, where strategies of technology deployment are negotiated - in the German production model typically between management and works council. (3) The arena of appropriation, in which different organizational technocultures offer contesting schemes for the actual use of technology at work. Whereas most recent research on digitalization of work conceptualizes workers as mere objects of digitalization processes, this paper focuses on worker agency as a "technopolitics from below." It thus demonstrates how workers influence the concrete outcome of digitalization projects.
\end{abstract}

Keywords Algorithmic management .

Appropriation · Digitalization · Implementation ·

Politics of production · Regulation · Unions ·

Workplace $\cdot$ Works councils

S. Schaupp $(\bowtie)$

University of Basel, Basel, Switzerland

e-mail: simon.schaupp@unibas.ch

\section{Introduction}

Algorithmic management-the direction, evaluation, and optimization of labor processes by software or digitalized means of production-is playing an ever increasing role in the rationalization of work. Consequently, the sociology of work has developed great interest in the topic within the last decade. Internationally, the overwhelming majority of studies research algorithmic management in the context of the so-called platform or gig economy [1-7]. In the German context, which will be central to this article, this focus is supplemented by studies that research algorithmic management in the context of manufacturing [8-12]. There is a consensus among those studies that at the level of the labor process, algorithmic management enables extensive surveillance and, in terms of employment relations, contributes to precarity. Thus, algorithmic management regularly seems to come at the expense of workers. If this is so, however, the question arises as to how workers react to this disadvantage. This question remains unanswered in most cases, as will be shown in detail below.

This problem becomes especially relevant in light of the proposed "Emancipatory Technology Studies" called for by this special issue. If we understand emancipation on a preliminary basis as the struggles of subaltern actors against different forms of domination [13], workers must be at the center of "Emancipatory Technology Studies" within the sphere of production. This article therefore suggests a multi-level framework for the analysis of "technopolitics from below," i.e., for 
the different forms in which workers influence the use of technology at work. This framework was developed over the course of a 4-year research project on algorithmic management of manual work in the sectors of manufacturing and delivery platforms in Germany.

The term technopolitics was first used during the period of the worldwide adoption of the Internet in the late 1990s [14]. In this context, technopolitics simply referred to "the use of new technologies such as computers and the Internet to advance political goals" ([15], p. 16). It was connected to the hope of a radical democratization of political discourses and of the public sphere more broadly. More recent iterations of the term technopolitics are also deployed with this sense of digitally mediatized communication [16, 17]. In what follows, the term is understood as "politics in production" [18] rather than communication. It furthermore refers to the domain of this politics concerned with negotiations over the design and use of technology. Most current approaches to the politics of digitalization ${ }^{1}$ in production are limited either to a macro-perspective on labor markets and institutional regulation of technology [20-24], or to conflicts at the immediate level of the labor process [25-28]. ${ }^{2}$ Yet only if we take into account the interactions between institutional regulation and the labor process can we build a complete picture of the relevant factors of any politics of production. The analytical framework of technopolitics thus develops a multi-level model of the different forms of negotiating technology in production. It sketches three "arenas," each with different logics of negotiation: (1) The arena of regulation, where institutional framings of technologies in production are negotiated, typically between state actors, employers' associations, and unions. (2) The arena of implementation, where strategies of technology deployment are negotiated-in the German production model typically between management and works council. ${ }^{3}$ (3) The arena

\footnotetext{
1 "Digitalization" here refers to the diffusion of digital technologies and corresponding practices in various areas of society, whereas "digitization" would describe the transformation of data into a digital form [19].

2 A remarkable exception is [1] which examines the gig economy in a multi-level analysis, with a focus on workers' agency.

3 The works council is an institution specific to the German model of industrial relations in which workers are granted the right to elect representatives at the company level with specific rights to information and co-determination. All companies studied here had a works council.
}

of appropriation in which different organizational technocultures offer contesting schemes for the actual use of technology in everyday work.

The first section of this article explains the methods used in the multi-case study from which the framework of technopolitics was developed. The second section reviews existing approaches on the digitalization of work and algorithmic management; it argues that the agency of workers in influencing the implementation of technology has not received appropriate attention. Consequently, the third section sketches the concept of technopolitics, emphasizing the specific form of a technopolitics from below. The following three sections are organized according to the different technopolitical arenas: regulation, implementation, and appropriation. Drawing on the empirical material of the case study, each section demonstrates how workers influenced the deployment of algorithmic management in each respective arena. The conclusion summarizes the results and discusses potential uses of the framework for future research.

\section{The Case Study}

The case study on which this article draws examined algorithmic control of manual work in Germany. It consisted of a "multi-case study" [29] focusing on four companies. As the sectors of industrial manufacturing and of delivery platforms witness the most widespread use of algorithmic management [30, 31], interview partners were sought in these sectors specifically. Initial interviewees were selected based on the recommendations of experts such as engineers and trade unionists. These subjects were then questioned about other relevant actors in the field, following a snowball system [32]. "Comprehensive interviews" [33] were then conducted with managers, works councils, workers, technology developers, and trade unionists in order to identify strategies for dealing with algorithmic management. On average, these interviews lasted for a little more than one hour. According to the strategy of the comprehensive interview, the informants were asked three general questions concerning their perspective on algorithmic management in their companies. Subsequently, follow-up questions were asked to deepen relevant aspects of the interviewees' narratives.

Based on these interviews and previous theoretical considerations, two companies from the sector of 
manufacturing and two platform delivery companies were selected as focus cases. The first manufacturing company will be called Smart Solutions. ${ }^{4}$ It is a large corporation in the chemical industry which had just invested in digital infrastructure at the time this study began. The second company, Smart Electrics, is a medium-sized mechanical engineering company in which the shop floor workforce is largely composed of highly qualified technicians. At the time of study, it was just beginning to implement algorithmic management. The first company drawn from the delivery platform sector was Smart Shopping, a multinational online retailer with several warehouses in Germany. It was chosen as the third focus case, as it offered the opportunity to study the algorithmically controlled "low-skilled" work of pickers and packers in the warehouses. The second platform, Smart Delivery, transports meals from independent restaurants to consumers via bicycle couriers. Workers are controlled algorithmically without any requirement of personal contact with supervisors. Smart Delivery's business model is considered to be among the vanguard of algorithmic management [25, 26, 34].

All focus cases were investigated using a combination of comprehensive interviews and participant observation [35]. Since interviews are not sufficient evidence on which to base conclusions about the use of technology, they must be supplemented by ethnographic analysis [36]. For this reason, the author worked at Smart Electrics and Smart Delivery to conduct participant observation. In the case of Smart Electrics, such observation was limited to two 1-week work assignments at an assembly line before and after the implementation of a digital work-control system. At Smart Delivery, it took the form of a 5-month employment as a mini-jobber. At Smart Solutions and Smart Shopping, participant observations were conducted at a series of multi-day works-council workshops on the topic of digitalization of production. Audio recordings of these workshops were made and complemented by field notes.

In total, 53 interviews were conducted and six months of participant observation carried out. The collected data were analyzed according to the program of the dual thematic framework analysis [37] which combines analysis

\footnotetext{
$\overline{4}$ The names of all focus companies have been changed.
}

of data from ethnographies and interviews and contrasts conflicting perspectives on the same subject.

\section{Technology Without Politics?}

It is widely understood within the social sciences that technology carries political implications for nearly all aspects of modern life [38-40]. Moreover, as we have seen above, there is a vast scholarly discourse on the digitalization of work generally, and as it relates to algorithmic management in particular. Yet, there is a curious asymmetry of analytical perspectives: while most social science studies on corporate digitalization analyze management as a strategically proceeding actor seeking to improve its position of power, workers appear as objects of these processes who lack their own strategic agency. This asymmetry occurs primarily in three variants: the critical managementcentered variant, the symmetricist variant, and the governmentality variant.

The critical management-centered variant focuses on the implementation side of technology at work in critically examining managerial control strategies and practices of engineers, while the agency of workers is left out of the picture. On this side of implementation, there is a continuous stream of innovations in social and technical control to be discovered, many of which promise to solve the problem of the structural indeterminacy of the labor process comprehensively [3, 4, 7, 41]. Theoretically, it was repeatedly postulated that the intentions of implementing both technologies and management strategies do conflict with their practical appropriation in the labor processes [42-44]. Yet, empirical analysis of algorithmic management often equates the presence of certain management strategies or technologies to the organizational practices as a whole. This risks taking management rhetoric at face value, albeit in a critical manner. By contrast, both the operational barriers to implementation of digital technology and autonomous appropriation practices of workers are systematically underestimated [45].

Obviously, there are many approaches which focus on the concrete interactions of humans and digital technologies in the workplace. Especially, science and technology studies (STS) have developed a variety of approaches emphasizing the symmetric co-constitution of technology and sociality. Studies on human computer interaction and workplace studies focus on interactions 
with technology at the level of individuals [46-48]. The enactment approach emphasizes the contingent cultural practices that are the precondition for the use of technology $[43,49,50]$. Approaches based on actor-network theory have argued for an understanding of agency as distributed in networks of human and non-human entities-including those composed of digital technologies [51-53]. Approaches based on new materialism have argued that human practices and technical apparatuses co-constitute each other in continuous "intra-actions" [54-56]. However, these approaches have been criticized for over-emphasizing symmetrical relationships and therefore not being able to take into account structures of domination or even fetishizing technology [57-59]. While some of these approaches mention "power" as a factor, they remain with an individualistic understanding of power that neglects more systemic structures of domination that define organizations in large part [60].

The third important variant of conceptualizing the relationship of workers towards algorithmic management is aligned to governmentality theory. It builds on Foucault's concept of the subject as an effect of power relations. Subjective desire is thus not considered as a possible origin of resistance but as the sum of its "technologies of the self" - and thereby becomes the central site of self-disciplining [61]. This concept of the subject was used to refer to the various self-disciplining and self-optimizing techniques of an "entrepreneurial self" that has become a dominant figure of the postFordist world of work [62]. For the sociological analysis of algorithmic management, this notion of subject became an important point of reference to mediate between the technical and the social dimension of control [63-67]. This focus on self-disciplining often leads to assumptions like: "Workers have internalized the imperative to perform, a subjectification process as we become observing entrepreneurial subjects and observed, objectified labouring bodies." ([68], p. 2774) Governmentality approaches to technology at work can thus be understood as a departure from an understanding of the subject, in which the self-disciplining and consensual involvement of workers was empirically diagnosed, but the subjective experiences of suffering in the capitalist production process always remained a point of reference for dissent $[69,70]$. This departure, however, risks to overvalue managerial control strategies and to veil practices of resistance.

There are of course notable exceptions to the tendency of neglecting workers' agency in the implementation of workplace technology. Especially in the sector of the platform economy, several studies have pointed out resistant practices of workers $[1,6,27]$. The newly revitalized tradition of worker's inquiry or co-research has brought about especially valuable perspectives on these instances of resistance $[25,26,28]$. Yet, resistance at the level of the labor process is not by any means the only approach by which workers attempt to influence the deployment of digital technologies. As will be demonstrated in what follows, a distinction between different levels of technopolitics, ranging from appropriation to regulation, may be drawn. This paper therefore develops an integrated framework for a multilevel analysis of the various forms of technopolitics and lays special emphasis on the agency of workers.

\section{The Technopolitics of Production}

Negotiations of the use of technology at work are situated within the context of industrial relations. As the capitalist organization of labor brings about various social conflicts, work is one of the central fields of politics in modern societies [71]. These politics take place both within the workplace and beyond it, e.g., when states regulate production. The most elaborate concept in integrating the analysis of these different levels is Burawoy's "politics of production" [18]. Central to Burawoy's concept of the politics of production is the interaction between the labor process and institutional regulation. Based on extensive ethnographic studies, Burawoy formulates three axes along which this dynamic may be analyzed: the difference between the politics of production and the political institutions that shape politics; the limitations imposed on both the labor process and on market forces; and third, the different modes in which politics and institutions at the level of production relate to politics and institutions at the level of the state ([18], p. 122-126). In this sense, the concept of the politics of production focuses on the interactions between production and its institutional framework:

Alongside the organization of work - that is, the labour process - there are distinctive political and ideological apparatuses of production which regulate production relations. The notion of production regime or, more specifically factory regime embraces both these dimensions of production politics. ([18], p. 7-8). 
Thus, the politics of production result in power relations, which set limits of action to workers as well as to management, the so-called "production regime". This opens up certain possibilities for action but restricts others. Burawoy's concept of the politics of production-especially with regard to its conception of the interaction of labor process and institutional regulation—-proves to be an important building block for understanding the negotiation of technology in work settings. However, it must be adjusted in several respects for the purposes of analyzing the specific problems presented by negotiations of technology. First, the implementation and use of technology must be identified as a subfield of the politics of production in its own right. I will refer to this subfield as technopolitics. Secondly, questions of scaling must be addressed. To this end, I propose transcending the distinction between labor process and regulation by addressing three distinct arenas of technopolitics.

German labor sociologist Müller-Jentsch [72] speaks of the different fields of industrial relations as "arenas of negotiation." Such arenas are understood as spaces for the regulated staging of conflicts and institutionalized conflict resolution and a "battlefield" where the respective actors not only seek to assert their conflicting interests $^{5}$ but also to influence the procedural framework of negotiation itself. In this sense, the arena is both a complex institutional system that determines which modalities, interests, and actors are permitted and a delimited field of conflict that gives the actors options for actionwith defined limits-for solving specific problems. This concept is productive for an analysis of technopolitical negotiations in that it emphasizes both the variance of rules and the conflictual nature of industrial relations. Above all, however, it enables further differentiation of specific places of negotiation beyond the distinction between labor process and institutional regulation. However, the concept of the arena, with its focus on regulated conflict resolution, is biased in favor of the representational politics of trade unions, works councils, and the like. This conceptualization may lead to a systematic underestimation of informal practices - precisely those of the greatest importance for technopolitics and production politics in general, as will be demonstrated below.

\footnotetext{
5 The genuinely political moment in the concept of technopolitics is emphasis on the negotiation of conflicting interests. The interests of workers and capital are at the center of this conflict-
}

Three arenas of technopolitics are to be treated separately: (1) The arena of regulation, in which the institutional framework for the use of technologies is negotiated. (2) The arena of implementation, where strategies for the introduction of concrete technologies into production processes are negotiated. While Burawoy [18] only distinguishes between regulation and labor process, it is necessary to insist on a distinction between the logics of implementation and appropriation of the technologies with regard to technology. Thus, the arena of appropriation (3) refers to the various and sometimes conflicting organizational cultures which determine the actual use of technology.

Although politics is most conspicuous where conflicts arise, it persists across consensual constellations. The concept of negotiation thus encompasses both cooperative and confrontational interactions, some of which are conducted implicitly, some explicitly. Such interactions can take place according to well-established rules and customary laws, in tacit agreements, conflictual "silent negotiations" or by means of formal agreements and contracts. All actors in these negotiation processes, including the workers themselves, are capable of developing strategic action.

Conflicts that take place within one arena and abide by its logic of negotiation may be termed intraarena conflicts. Negotiations may also transcend their arena in inter-arena conflicts. Such cases arise when organizational practices run counter to institutional regulations or when technologies are used in a manner that deviates from the intent of their implementation. In general, the possibility of an accumulation of potential conflicts depends largely on how permeable arena boundaries are with respect to their modes of negotiation. If individual arenas are governed by different negotiation logics, if different actors are responsible for negotiations and other interests determine the agenda, a "leap" of conflicts from one arena to another becomes unlikely and the coexistence of

\footnotetext{
Footnote 5 (continued)

even if there are other regular lines of conflicts within firms: those between white-collar and blue-collar workers, between business people and technicians, between men and women, between old and young, etc. Goals, strategies and decisions cannot be derived solely from a set of objective interests. Instead, they are always shaped by normative and political-ideological orientations on the one hand, and by considerations of possibility for action and chances of success on the other ([73], p. 580).
} 
conflicts in one arena with cooperation in the other becomes possible ([72], p. 59). The extent to which such leaps actually occur therefore requires empirical verification.

This article emphasizes a specific form of technopolitics, namely technopolitics from below. This refers to the power asymmetry of actors in various arenas. Ordinary workers have the opportunity to resist certain technologies given their position in the production process. However, they can only rarely decide directly the questions of technology design and implementation, and even less frequently influence legal and other regulations. "Below" thus signifies the position of actors on the lower end of structures of domination. ${ }^{6}$ In the context of capitalist production, workers find themselves in such a position structurally, because they are controlled by their superiors in management. Anderson refers to these corporate structures of domination as "private governments" [75]. "Politics from below," then, signifies struggles against a specific form of domination by those actors who are subjugated to it [76]. In the case of technopolitics, this for example refers to resistant practices in the arena of appropriation, which may influence the higher-level arenas. Thus, stepped-up technological disobedience can lead to the transformation or even abandonment of projects of technology implementation. Such outcomes, in turn, may rebound to the institutional arena; sometimes even institutional regulations may be forced to adapt. However, it is important to keep in mind that actors who are negatively affected by a certain relation of domination (e.g., workers in the capital relation) may be privileged by patriarchal, racial, or other relations of domination [77]. This means that the position of "below" is connected to social context rather than to specific persons. Thus, workers in a capitalist firm have in common that they are affected by corporate domination, but are they also divided along other lines of domination and discrimination, which is especially relevant for their capacity to act collectively.

The possibilities for workers to influence politics of production in general or technopolitics in particular is dependent on the power resources available

\footnotetext{
${ }^{6}$ Bourdieu, for example, uses the term "below" in his stratified model of the social field to refer to the position of subordinate actors [74].
}

to them. The extant literature usually divides these resources into organizational power and structural power [78-81]. Workers build organizational power in order to pursue their interests by organizing in trade unions or political parties. Additionally, workers maintain structural power given their position in the production process. This position may again be differentiated further as market power and production power. Workers have market power when firms cannot replace them due to tight labor markets. Firms are then dependent on these workers and are less able to withstand strikes, for example. By contrast, production power is based on the strategically important position of workers in the context of production generally. Various studies show, for example, how the introduction of "lean production" has given workers new forms of production power, since the "just-intime" imperative has made supply chains more vulnerable to disruptions [82-86]

A problem of the power resource approach (PRA) for the analysis of technopolitics from below, however, is that it does not make a sufficient distinction between the various forms of power and the divergent political logics entailed by them. The question of what sources of worker power can be identified is usually answered through an analysis of the power of trade unions [80] or workers' parties [81]. In this regard, the PRA differentiates workers' power into primary and secondary power [78], or into structural power and organizational power [80,81], while assuming a direct transfer of the same interests across political levels. On the one hand, it is evident that workers can only build up power if they organize in some capacity. On the other hand, this implies in most cases a shift from "first person politics" to representational politics. ${ }^{7}$ Collective actors such as unions can enter into negotiations with representatives of the employers' side. These negotiations result in collective agreements or state regulations, which in turn define new frameworks for the mediation of conflicting interests $[88,89]$. Representational politics of this type is always confronted with the dilemma of power. Thus, every delegation of power to a higher level by

\footnotetext{
7 The company level of this representation includes informal workers groups - and in Germany especially, works councils [87]. Equally important, however, is supra-company representation in trade unions and political parties $[81,86]$.
} 
definition increases its distance from its social base, and thereby also the probability of an emergent, separate, and institutionalized self-interest. A substantial literature has shown that, in the course of the institutionalization of trade unions and parties, these institutions develop their own institutional logics which do not necessarily coincide with those they are meant to represent [90-92]. Thus, German trade unions are regularly conceptualized as "intermediary organizations" [93]: they mediate between capital and labor. Assuming a direct transfer of workers' interests to the institutional representative bodies of trade unions and parties is therefore mistaken. Nevertheless, institutionalized politics must be considered when analyzing workers' technopolitics. The question of whether a given practice is part of a technopolitics from below can therefore only be answered empirically and not a priori. It must be approached by way of consideration of all three technopolitical arenas.

\section{The Arena of Regulation}

The arena of institutional regulation can be defined in relation to what Burawoy [18] calls the "political apparatuses of production." This is where the institutional framework of technopolitics is negotiated. The role of such regulations for technological development has been studied in multiple contexts. Governmental policy represents an essential institutional basis for technological development [22]. ${ }^{8}$ For our purposes, the role of the state in the emergence of algorithmic management is important as well. However, it must be supplemented with two additional groups of actors: business associations and trade unions. Only by taking them into account is it possible to understand technopolitical regulation as a process of political negotiation. Technopolitical regulation is understood here as the arena in which state institutions, business associations and trade unions negotiate the institutional framework of technology deployment. The analytical focus is thus on both policy measures already underway and on regulatory discourses through which

\footnotetext{
${ }^{8}$ Kushida [21] shows how different governmental liberalization strategies in the telecommunications sector have become the starting point of divergent digitalization paths. Montalban and others [23] also emphasize the role of the state in the formation of the platform economy, using a classical regulation theory approach (see also [24]).
}

demands for future changes are made. These two levels are closely intertwined, since institutional discourses primarily have a mobilization function [94]. To illustrate this, I will draw on the empirical material of the study on the technopolitics of algorithmic management in manual work in Germany.

The logic of negotiation in the arena of regulation was centered on national economic advantages. Yet, the institutional framing of algorithmic management was negotiated quite controversially. Both the modes of negotiation and the results of technopolitics in the regulation arena provided important conditions for the implementation of algorithmic management within companies. German business associations have accompanied the latest wave of digitalization in production with a push towards the deregulation of employment relations [95]. Those employers and managers interviewed for the study called for the abolition of working time regulations, the restriction of co-determination in companies, and the relaxation of data protection in order to adapt the labor market to digitalization. Since all of these demands come at the expense of workers, trade unions have taken an opposing position in most areas. An important function of governmental technopolitics has been to mediate between these positions.

The technopolitics of the state actors researched here was characterized by a mixture of subsidization and mediation of digitalization projects under the label "Industrie 4.0" [96]. At the institutional level, bodies such as the state-led "Plattform Industrie 4.0" brought together actors from business associations trade unions and engineering. At the company level, "experimental spaces" established new practices of corporate digitalization by consensually exempting these spaces from existing regulations [97, 98]. ${ }^{9}$ Both formats aimed at pushing digitalization forward in a consensual manner [96]. This constellation can be described as techno-corporatism 4.0. It is characterized by the participation of the trade unions in the implementation of digitalization [97]. Thus, interviewed union officials emphasized that they "get a foot in the door" and are granted a say in the concrete design of digitalization processes in return for their participation.

Traditional corporatism in Germany depended on a centralist model of industrial relations which allowed for

9 Such an "experimental space" was observed here in the case of Smart Electrics. 
"elite deals" among the heads of the respective interest groups $[99,100]$. This does not appear to be the case with techno-corporatism. On the contrary, the latter, with its intra-organizational experimental spaces, is characterized by a partial shift of trade union technopolitics to the company level. It is thus part of a process of controlled decentralization [101] of industrial relations in Germany. What is characteristic here is not elite dealmaking, but rather the adoption of business management logic by unions and works councils in the course of participation in projects of technology implementation. With this technocorporatism, a design-oriented, cooperative model of trade union technopolitics has emerged within the German manufacturing sector. From the trade union point of view, this model has been partially successful. For example, the full automation-utopias of previous digitalization programs like "Computer Integrated Manufacturing" [102] has been abandoned. Instead, "Industrie 4.0" has taken the slogan "people at the center" as its motto and in some cases even promised the "reshoring" [103] of manufacturing jobs. With regard to data privacy, trade unions and works councils have so far been able to avert radical digital surveillance of workers. In this effort, they made use of the German Works Constitution Act (Betriebsverfassungsgesetz) and the European General Data Protection Regulation (GDPR). On the other side, by adopting the idea of flexibilization, employer-led partial deregulation has been partially accepted.

Techno-corporatism also caused inter-arena conflicts, however. The design-oriented, cooperative model of trade union technopolitics went with participation in concrete technology implementation and thus with the adoption of a business management logic. For some of the interviewed workers and works councils, this in turn led to alienation from the trade unions. A typical accusation made over the course of the interviews was that "the fighting spirit is no longer present in the unions." This was also expressed in the tendency to decouple a technopolitics from below from the trade union organizations and a turn towards informal disputes. One example for this phenomenon from the case study is an informal workers group at Smart Solutions, which pressured management with go-slow strikes at a certain "choke point". It is therefore doubtful whether the design-oriented, cooperative model of trade union technopolitics will prove to be stable.

In the platform delivery sector, the situation was somewhat reversed. This sector is not subsidized by the German state, but on the contrary is often depicted as the undesirable other of industrial digitalization. This also means that the institutions characteristic of German industrial relations [104] are very rarely operative in this sector, ${ }^{10}$ not least because unions have neglected it for quite some time. The design-oriented, cooperative model of trade union technopolitics had little chance of asserting itself in the platform sector, as a consequence. Instead, an antagonistic mode of negotiation emerged that largely followed the principles of social movement unionism [105, 106]. For the case of Smart Delivery, this has meant that workers have organized in a grassroots union and have conducted informal strikes ("logout actions") as well as protest rallies. At Smart Shopping, the workers organized themselves through an established union, which was, however, forced by the antagonistic nature of negotiations to apply unusually confrontational tactics. Yet whenever such social movement unionism was successful, new steps towards institutionalization, such as the establishment of works councils, got under way. These in turn, according to their structural logic, contributed to a defusing of the antagonistic mode of technopolitics. Thus, neither the design-oriented, cooperative, nor the antagonistic model of trade union technopolitics appears to be stable in the long term.

The results of the negotiations in the arena of regulation prefigured the settings of the arenas of implementation and appropriation. The case study identified four key results of these negotiations. The first is that no full automation has been pursued. This is primarily due to politico-economic factors [107] but the participation of trade unions in the institutions of "Industrie 4.0" also contributed to this strategy. Secondly, new data protection regulations put legal limits to classical surveillance. Thirdly, employers were largely successful with their demands for digitalization to go along with more flexibility in employment relations. Fourthly, on the question of worker skills, employer and worker representatives were largely in agreement in their demands for additional IT

\footnotetext{
$\overline{10}$ Both Smart Shopping and Smart Delivery did have a works council at the time of the study; however, management in both cases took a relatively hostile stance towards this institution.
} 
training. These central issues also structured the technopolitical negotiations in the arenas of implementation and appropriation and will be discussed again in the corresponding sections.

In sum, unions are the central instrument of a technopolitics from below in the arena of regulation. However, a direct translation of workers' interests into union politics cannot be assumed a priori, as we have seen above. In our case, a design-oriented cooperative and an antagonistic mode of union technopolitics emerged in the fields of industrial production and platform logistics, respectively. In both modes, workers were able to bargain for some technopolitical concessions, but both suffer from internal contradictions, which make it unlikely for them to remain stable in the long term. The following sections will approach technopolitics at the organizational level.

\section{The Arena of Implementation}

The German Works Constitution Act provides that questions of work design be negotiated between management and works council. As technology heavily influences the design of work, works councils are entitled to information and partial co-determination regarding the implementation of new technology. Still, works councils cannot fundamentally block rationalization projects. This ambivalence results in a large empirical variance in works council action, ranging from co-management to class struggle [87]. This also translates to a wide variety of works council stances on digitalization. Contrary to the reputation of works councils as a brake on innovation, no empirical evidence exists to suggest that companies with works councils should expect lower levels of digitalization [108].

Negotiations in the arena of implementation are mostly dominated by a business management logic. Thus, technology implementation is usually part of rationalization strategies aimed at increasing productivity. Pfeiffer ([60], p.14) distinguishes three general goals of the "technization" of work: (1) reducing necessary labor, (2) increasing efficiency, and (3) process control. From these goals, the central conflict potential in the technopolitical arena of implementation arises. The use of technology, and in particular the mechanization of work in production, always aims either to replace living labor or to change its content.
The companies in the present case study pursued all three of these goals.

Automation as the classic form of reducing necessary labor was observed in the case study mainly in one specific form of data-driven automation, which aims to use data from the labor process as the basis for software- or AI-based automation. Such was the case, for example, when the tracking data of human intra-logistics workers were used to build driverless transport systems. However, automation occurred to a much lesser extent than might be expected, given the scientific discourse on the topic [109-111]. The surveyed works councils were highly sensitive to the topic of job losses due to automation and were able to enforce a steady net level of staffing. In all researched companies, far-reaching automation in the area of manual labor in production and logistics was prevented by the cheap price of human labor relative to advanced robotics. In all four focus cases, management instead chose to implement digital assistance systems, which allowed for a lowering of qualification requirements with the aim of integrating cheaper labor. " $\mathrm{We}$ are really shifting work to less qualified and therefore cheaper workers, sure," a manager of Smart Electrics stated. Migrants were a major source of such cheap labor. Thus, at some of the locations of Smart Delivery and Smart Shopping, migrants accounted for a majority of the workforce. The companies integrated them into the production processes through digital assistance systems that eliminated the necessity of speaking the native language. The surveyed works councils were less sensitive to this issue of digital de-skilling, and only occasionally aimed to reach agreements with management regarding the re-qualification of workers.

An increase in efficiency was aimed at in regard to algorithmic management mainly in the form of flexible workforce allocation. Thus, the workflows, simplified via the assistance systems, largely eliminated the need for training processes. This makes it easier both to move existing workforces within the company and to integrate temporary workers more easily. Thereby, it reduces, in relative terms, the number of workers needed for flexible production. In the case of

\footnotetext{
11 It is generally assumed that the major effect of digitalization on labor markets is a polarization in terms of skills [90-92]. The emphasis on de-skilling is not aimed at challenging this thesis but is due to the fact that the object of research was manual work, where de-skilling clearly outweighs upgrading.
} 
the food courier company Smart Delivery, algorithmic management was the technical precondition for a radical flexibilization of workforce allocation: shifts were assigned to the couriers by an algorithm and smartphone-based algorithmic management allowed for the spatial de-coupling of labor process and company. Thus, time sovereignty was a central topic of negotiation between management and works councils. In all cases, these negotiations led to restrictions in the companies' pursuit of flexibilization in order to protect the autonomy of workers in choosing their working hours.

The main effort for algorithmic process control in the researched companies was digital surveillance. It is well established that digital technology enables extreme forms of surveillance of labor processes [41]. However, this technical possibility is limited by technopolitical negotiations in the arenas of regulation and implementation. As we have seen in the previous section, legal regulations heavily restrict digital surveillance. On the basis of these laws, the surveyed works councils were able to prevent most of management's attempts to expand classical surveillance to the extraordinary degree now available to it. ${ }^{12}$ Instead, another mode of control has emerged that can be termed a cybernetic one [8]. Thereby, data on labor processes was used primarily for immediate feedback to workers. These were then expected to "tune themselves" according to the feedbacks, as one manager put it. In this way, a continuous optimization process was to be set in motion, which differed from the standardized time targets of Taylorism. As with the latter, cybernetic control also aimed to digitally identify and eliminate "time waste" and thus to intensify work. The cybernetic logic of feedback initially seemed attractive both for management and for some works councils, as it can theoretically be implemented without central storage of data. Although this allayed privacy concerns of some works councils, it reinforced rather than cushioned the problems of constant work intensification. Most of the works council members surveyed were well aware of these dangers. Some of them tried to combat such intensification by means of agreements on health protection, which

\footnotetext{
12 A central negotiating instrument was the co-determination requirement for all implementation projects that can be used to monitor performance, i.e. virtually all digital technologies.
}

were intended to reduce stress levels. Yet, unlike data protection, works councils had fewer legal options for exerting pressure in this area.

In all cases, it became clear that both management and the works councils had much at stake when it came to algorithmic management. This also explains the contentiousness of the negotiations reconstructed in this study. Nevertheless, it is important to stress that works councils are intermediary institutions in technopolitical negotiations [87, 93]. Even more than trade unions, works councils are committed to the preservation of their companies, and as a result support most rationalization measures. In concrete terms, this means that although the surveyed works councils were able to avert various data protection violations, they had to accept the rationalization measures informing them in one form or another. As we will see in the next chapter, this inevitable incorporation of works councils into management logic regularly led to alienation from the workforce in some cases. Thus, the question whether the works councils' efforts for a humane digitalization can be described as a technopolitics from below depends on the degree to which workers can influence the strategies of the works council, i.e., the democratization of co-determination in the workplace. As the following section will demonstrate, inter-arena conflicts emerged between the logics of control in the arena of implementation (to which works councils also contributed) and the logics of appropriation-that is, the workers' actual use of the implemented technologies.

\section{The Arena of Appropriation}

Technology appropriation here refers to the cultural references to and practical use of technologies by workers [43, 44]. It does not so much concern individual practices, but rather shared cultural schemes which are always part of cooperation and communication within a company [112]. The logics of these appropriation processes differ structurally from the logics of implementation strategies. Thus, when dealing with technologies in the labor process, organizational technocultures emerge. The term technoculture is usually understood as the digitally mediatized form of cultural expression [113-115]. A differentinterpretation will be used here, the term is used to refer to that part of the organizational culture, which assigns social significance to technologies [116]. 
When workers interact with a given technology, the routines of use do not simply emerge at a contingent, individual level, as some approaches to technology appropriation imply. Instead, the organized use of technology in the workplace is primarily determined by organizational hierarchies. Therefore, deviations from the official schemes of the use of technology also imply a form of "organizational disobedience" [117]. In this sense, a distinction can be made between official and subcultural organizational technocultures. ${ }^{13}$ While the former propagates a use of technology in accordance with organizational goals, the latter reflects autonomous practices of workers. In this sense, the ways in which workers appropriate technologies depend to a large extent on supra-individual technocultures. These technocultures can deviate significantly from management's ideas about the respective technologies—which constitute official organizational technocultures. ${ }^{14}$ Such official organizational cultures never succeed in fully determining the interpretation of reality. As no organization can determine every action of its members, reflexivity and thus the possibility of criticism remain part of all organizational practices: while domination on a cultural level depends on defining what is real, this definition is always contestable, and alternative definitions of reality can be established. These then prepare the ground for manifest critique. This is what Boltanski [13] calls the "hermeneutic contradiction". In terms of the appropriation of technology, it is not only a matter of defining the function of specific technologies in the production process, but also about the identity of the technology, i.e., its significance in terms of organizational culture. This is how organizational subcultures emerge. Subcultures can challenge, modify or even replace the official culture. In some cases, they develop as an explicit antagonism to the official organizational culture, and thereby carry forward critical or resistant technocultures $[118,119]$.

In the case study presented here, a central issue in the cultural appropriation of technologies consisted in naming and thus defining machines. While management tried to establish identities that emphasized technological potentials and possibilities, workers established

\footnotetext{
${ }^{13}$ On the distinction between official organizational culture and subculture see [118].

14 Official organizational culture can be defined as a set of arbitrary symbols and structures of meaning arranged according to management preferences ([118] p. 170).
}

identities that ridiculed technology by emphasizing its technical dysfunctions and its role as instruments of control. In the two researched manufacturing companies, the central cultural practice that led to such critical technocultures was subversive humor. The workers gave the new technologies derisive names such as "Fiff", 15 for an autonomous transport robot or "the sex toy" for a digital control glove that vibrated if it registered undesired movements. This form of subversive humor is a relatively riskless variant of critique: it addresses real problems, but the use of humor provides cover to workers.

In the platform company Smart Delivery, such subversive humor occurred only very rarely during the participant observation. The couriers' criticism of algorithmic management and their employment relationships in general was much more direct and open. This can be explained by the fact that workers were exclusively controlled by algorithms and no managers were physically present. In this way, critical technocultures could establish themselves much more safely and openly than under conditions of personal co-presence of management and workers.

In the everyday actions of workers, such resistant technocultures may translate into technological disobedience. Technologies may be used contrary to the intentions of implementation. While open sabotage is relatively rare in everyday working life, the "misuse" of technology appears to be the norm rather than the exception [117, 120]. For example, workers generally use technology in their everyday work in such a way that it eases, or at least does not make more strenuous, the task at hand. The cases studied here contain a large number of examples of such technological disobedience. This ranged from manipulating algorithms to purposefully crashing digital systems in protest against algorithmic management [121].

In all four cases, the critical technoculture became the basis for resistant practices, as it fulfilled the function of a permanent mutual assurance of a common critical attitude between the workers. These resistance practices took place both individually and collectively. Workers at Smart Delivery, for example, tried to manipulate the algorithms of their delivery app, while workers at Smart Solutions tried to use the information from the work control systems to add breaks to their schedule. Such organizational disobedience usually

\footnotetext{
${ }^{15}$ Fiffi ist the stereotypical German name for a stupid dog.
} 
takes place on the individual level and includes all those actions workers carry out against explicit or implicit instructions [117]. However, such actions can only be described as explicitly resistant if they assume a strategic dimension. This usually goes hand in hand with a form of coordinated action, as in, for example, go-slow strikes or even sabotage. Thus, in the case study, in one instance, workers coordinated a collective slow-down, which was especially effective against the cybernetic mode of control: as the algorithms (which had substituted supervisory personnel) calculated performance targets from the tracking data of the actual labor process, the workers managed to influence these targets themselves. Sabotage also occurred in one case where workers incapacitated the digital infrastructure of an intra-logistics department. In all cases, workers' practices of appropriation influenced the implementation of algorithmic management. At Smart Delivery, for example, the continuous development of the control app took the form of an arms race between the company and the appropriation strategies of the workers. In the case of the aforementioned digital glove, the distinctive logic of appropriation became especially evident. While the glove had been implemented with the approval of the local works council, its control function caused outrage among many workers. Thus, they constantly misused the glove while it was introduced, which led to the cancellation of its implementation. In one group interview, managers even stated that they would refrain from implementing any new wearable technologies, as these would encounter too much resistance on the shop floor.

In summary, workers themselves pursue technopolitics in their everyday work through a wide range of appropriation practices. The case study discovered a surprisingly wide discrepancy between the logics of implementation and of appropriation. While, for example, digital feedback technologies were aimed at establishing imperatives of self-optimization, in most cases, the workers' technocultures emphasized technology's control function and advanced a critical perspective of it. Establishing different forms of critical organizational technocultures became the basis of resistant practices, which in turn altered many of the implementation projects.

\section{Conclusion}

This article suggested an analytical framework for the analysis of a politics of production concerning technology. With this framework, the paper aims to develop the conceptualization of an "Emancipatory Technology Studies" called for by this special issue. While even critical studies of digitalization largely ignore it, it is precisely workers' agency that must be a starting point if we care to understand struggles for emancipation in relation to technology in production. Such struggles take varied forms. Typically, they are divided into conflicts at the level of the labor process and institutional politics, e.g., in unions. This paper has therefore developed a framework for the multi-level analysis of a technopolitics from below. Regulation, implementation, and appropriation have been articulated as arenas of technopolitics with distinctive logics of negotiation. The different negotiation logics of the arenas were illustrated by drawing on a multi-case study of the algorithmic control of manual work in manufacturing and delivery platforms in Germany.

In the arena of regulation, the two sectors discussed revealed quite different modes of negotiation. The delivery platform sector is characterized by an antagonistic mode of negotiation. Because it has been neglected by official unions for some time, workers at Smart Delivery have joined a grassroots union, while workers at Smart Shopping pressured their union to escalate confrontation as a tactic. In manufacturing, by contrast, a framework of techno-corporatism is emerging, in which the regulation of technology is negotiated in a consensual and design-oriented manner. Yet, in the cases of Smart Solutions and Smart Electrics, this approach led to the alienation of workers who were critical of the digitalization. Consequently, they partly decoupled their technopolitics from the official union line. A technopolitics in the arena of regulation, this case demonstrates, does not only take the form of unionized workers influencing institutional technopolitics, but perhaps relies even more fundamentally on the struggles of representation within the unions.

In the arena of implementation, we have seen how works councils tried to influence concrete strategies of digitalization within their companies. By drawing on legal frameworks negotiated in the arena of regulation, works councils in all cases were able to restrict management's plans for implementing digital surveillance. Moreover, in all cases, works councils criticized algorithmic management as a means of work intensification. In one case, they successfully 
negotiated for the gains in working speed to be offset by additional free time. Yet works councils, as with unions, are bound to specific institutional regulations, which sometimes separate them from a technopolitics from below. Thus, in one case, the works council approved a digital glove designed to control the labor process, which met stark resistance on the shop floor.

The arena of appropriation encompasses the most strident forms of a technopolitics from below. In this arena, direct action such as collective critique, intentional misuse of technology, or even sabotage has been observed. While these are arguably also the least influential form of technopolitics, we have seen several instances in which appropriation practices successfully changed strategies of technology implementation. Collective technocultures thereby play an important role in transforming "technological disobedience" of individuals into strategic collective practices.

The framework of a technopolitics from below is useful for the analysis of workers' influence over the use of technology at work. Although this article focused on algorithmic management, the framework may be applied to the negotiation of other types of technology as well. In contrast to most industrial relations approaches, it is not limited to institutionalized forms of negotiation, but emphasizes the importance of informal practices. This approach is therefore particularly useful in situations where technology implementation leads to conflict; other approaches may be more appropriate for analyzing consensual constellations. In terms of power resources, the framework of a technopolitics from below deviates from other approaches in its critical perspective of workers' interests as they relate to their institutional representative bodies. The framework does not assume fidelity between the two. Thus, the question if the politics of works councils in the arena of implementation, or of unions in the arena of regulation both form part of a technopolitics from below, can only be answered empirically. To do so, the term inter-arena conflicts was mobilized to describe collisions between negotiation logics in the different arenas. The term also underscores the dilemma of power: with every delegation of power to a higher level, the distance from its social basis grows, and the probability of the emergence of institutional self-interests increases. "Emancipatory technology studies" in the sphere of production must keep this in mind without limiting itself only to immediate conflicts at the level of the labor process.
Acknowledgements The author thanks Oliver Nachtwey and Uli Meyer for their valuable feedback at different stages of the research project.

Funding Open Access funding provided by Universität Basel (Universitätsbibliothek Basel).

Open Access This article is licensed under a Creative Commons Attribution 4.0 International License, which permits use, sharing, adaptation, distribution and reproduction in any medium or format, as long as you give appropriate credit to the original author(s) and the source, provide a link to the Creative Commons licence, and indicate if changes were made. The images or other third party material in this article are included in the article's Creative Commons licence, unless indicated otherwise in a credit line to the material. If material is not included in the article's Creative Commons licence and your intended use is not permitted by statutory regulation or exceeds the permitted use, you will need to obtain permission directly from the copyright holder. To view a copy of this licence, visit http://creativecommons.org/licenses/by/4.0/.

\section{References}

1. Woodcock J, Graham M (2020) The gig economy: A critical introduction. Polity, Cambridge

2. Rosenblat A (2018) Uberland: How algorithms are rewriting the rules of work. University of California, Oakland

3. Wood AJ, Graham M, Lehdonvirta V, Hjorth I (2019) Good gig, bad gig: Autonomy and algorithmic control in the global gig economy. Work Employ Soc 33:56-75

4. Veen A, Barratt T, Goods C (2019) Platform-capital's 'App-etite' for control: A labour process analysis of fooddelivery work in Australia. Work Employ Soc. https://doi. org/10.1177/0950017019836911

5. Heiland H (2021) Controlling space, controlling labour? Contested space in food delivery gig work. New Technol Work Employ. https://doi.org/10.1111/ntwe.12183

6. Kellogg KC, Valentine MA, Christin A (2019) Algorithms at work: The new contested terrain of control. Acad Manag Ann 14:366-410

7. Duggan J, Sherman U, Carbery R, McDonnell A (2020) Algorithmic management and app-work in the gig economy: A research agenda for employment relations and HRM. Hum Resour Manag J 30:114-132

8. Schaupp S, Diab RS (2019) From the smart factory to the selforganisation of capital: "Industrie 4.0" as the cybernetisation of production. Ephemera. Online first: http://ephemerajournal. org/contribution/smart-factory-self-organisation-capital$\%$ E2\% $80 \% 98$ industrie-40\%E2\%80\%99-cybernetisationproduction. Accessed 26 Nov 2019

9. Butollo F, Ehrlich M, Engel T (2017) Amazonisierung der Industriearbeit?: Industrie 4.0, Intralogistik und die Veränderung der Arbeitsverhältnisse in einem Montageunternehmen der Automobilindustrie. Arbeit 26:33-59

10. Raffetseder EM, Schaupp S, Staab P (2017) Kybernetik und Kontrolle. Algorithmische Arbeitssteuerung und betriebliche Herrschaft. PROKLA 187:229-247 
11. Evers M, Krzywdzinski M, Pfeiffer S (2019) Wearable computing im Betrieb gestalten. Arbeit 28:3-27

12. Krzywdzinski M, Gerber C, Evers M (2018) The social consequences of the digital revolution. Università $\mathrm{Ca}$ ' Foscari Venezia, Italia

13. Boltanski L (2011) On critique: A sociology of emancipation. Polity, Cambridge

14. Kellner D (1997) Intellectuals, the new public spheres, and technopolitics. New Polit Sci 169-188

15. Kellner D (2001) Globalisation, technopolitics and revolution. Theoria 48:14-34

16. Carpenter CA (2010) The Obamachine: Technopolitics 2.0. J Inf Technol Polit 7:216-225

17. Kahn R, Kellner D (2007) Globalization, technopolitics, and radical democracy. In: Dahlberg L, Siapera E (eds) Radical Democracy and the Internet: Interrogating Theory and Practice. Palgrave Macmillan, London, pp 17-36

18. Burawoy M (1985) The Politics of Production: Factory Regimes Under Capitalism and Socialism. Verso, London

19. SeibtD, Schaupp S, Meyer U (2019) Toward an analytical understanding of domination and emancipation in digitalizing industries. In: Meyer U, Schaupp S, Seibt D (eds) Digitalization in Industry - Between domination and emancipation. Palgrave, London, pp 1-25

20. Dyer-Witheford N (2015) Cyber-proletariat: Global labour in the digital vortex. Pluto Press, Toronto

21. Kushida KE (2015) The politics of commoditization in global ICT industries: A political economy explanation of the rise of Apple, Google, and Industry Disruptors. J Ind Compet Trade 15:49-67

22. Mazzucato M(2015) The entrepreneurial state. Anthem Press, London

23. Montalban M,Frigant V,Jullien B (2019) Platform economy as a new form of capitalism: A Régulationist research programme. Camb J Econ. https://doi.org/10.1093/cje/bez017

24. Thelen K (2018) Regulating Uber: The politics of the platform economy in Europe and the United States. Perspect Polit 16:938-953

25. Cant C (2019) Riding for Deliveroo: Resistance in the New Economy. Polity, Cambridge

26. Leonardi D, Murgia A, Briziarelli M, Armano E (2019) The ambivalence of logistical connectivity: A co-research with Foodora Riders. Work Organ Labour Glob 13:155-171

27. Tassinari A, Maccarrone V (2019) Riders on the storm: Workplace solidarity among gig economy couriers in Italy and the UK. Work, employment \& society: A journal of the British Sociological Association. https:// doi.org/10.1177/0950017019862954

28. Woodcock J (2017) Working the Phones: Control and Resistance in Call Centers, Reprint. Pluto Press, London

29. Yin RK (2003) Case Study Research: Design and Methods. SAGE, Thousand Oaks

30. Altenried M (2019) On the last mile: Logistical urbanism and the transformation of labour. Work Organ Labour Glob 13:114-129

31. Hirsch-KreinsenH(2016)Digitization of industrial work:Development paths and prospects. J Labour Mark Res 49:1-14

32. Noy C (2008) Sampling knowledge: The hermeneutics of snowball sampling in qualitative research. Intl J Soc Res Met 11:327-344
33. Kaufmann JC (2015) Das verstehende Interview. Theorie und Praxis (2nd ed.). UVK, Konstanz

34. Ivanova M, Bronowicka J, Kocher E, Degner A (2018) The App as a Boss? Control and Autonomy in ApplicationBased Management. Europa-Universität Viadrina, Frankfurt/ Oder

35. Burawoy M(2009) The extended case method - four countries, four decades, four great transformations, and one theoretical tradition. University of California, Berkeley

36. Heiland H, Schaupp S (2020) Digitale Atomisierung oder neue Arbeitskämpfe? Eine Ethnografie widerständiger Solidaritätskulturen in der plattformvermittelten Kurierarbeit. Momentum Quarterly 9:50-67

37. KalbermatterJ(2020) Bleiberechtin derGastro-Küche: Migrationspolitische Regulierungen und Arbeitsverhältnisse von Geflüchteten mit unsicherem Aufenhaltsstatus. Seismo, Zürich

38. Feenberg A (2002) Transforming technology: A critical theory revisited. Oxford University Press, New York

39. Illich I (2001) Tools for conviviality. Marion Boyars, London

40. Winner L (1980) Do artifacts have politics? Daedalus 109:121-136

41. Zuboff S (2019) The age of surveillance capitalism: The fight for the future at the new frontier of power. Profile Books, London

42. Leonardi PM (2013) Theoretical foundations for the study of sociomateriality. Inf Organ 23:59-76

43. OrlikowskiWJ(2000)Using technology and constituting structures: A practice lens for studying technology in organizations. Organ Sci 11:404-428

44. DeSanctis G, Poole MS (1994) Capturing the complexity in advanced technology use: Adaptive structuration theory. Organ Sci 5:121-147

45. Thompson P (2016) Dissent at work and the resistance debate: Departures, directions, and dead ends. Stud Polit Econ 97:106-123

46. Crabtree A, Mortier R (2015) Human data interaction: Historical lessons from social studies and CSCW. In: ECSCW 2015: Proceedings of the 14th European Conference on Computer Supported Cooperative Work, 19-23 September 2015. Springer, Oslo, pp 3-21

47. Luff P, Hindmarsh J, Heath C (2000) Workplace studies: Recovering work practice and informing system design. Cambridge University Press, Cambridge

48. Preece J, Rogers Y, Sharp H et al (1994) Human-computer interaction. Addison-Wesley Longman, Boston

49. Beane M, Orlikowski WJ (2015) What difference does a robot make? The material enactment of distributed coordination. Organ Sci 26:1553-1573

50. Sachs SE (2020) The algorithm at work? Explanation and repair in the enactment of similarity in art data. Inf Commun Soc 23:1689-1705

51. Latour B (2005) Reassembling the social: An introduction to actor-network-theory. Oxford University Press, Oxford

52. Cresswell KM, Worth A, Sheikh A (2010) Actor-network theory and its role in understanding the implementation of information technology developments in healthcare. BMC 10:67. https://doi.org/10.1186/1472-6947-10-67 
53. Kinder E, Jarrahi MH, Sutherland W (2019) Gig platforms. An Actor-Network Perspective. Proc ACM Hum-Comput Interact, Tensions, Alliances and Ecosystems. https://doi. org/10.1145/3359314

54. Barad K (2007) Meeting the universe halfway: Quantum physics and the entanglement of matter and meaning. Duke University Press, Durham

55. Coole D, Frost S (2010) New materialisms: Ontology, agency, and politics. Duke University Press, Durham

56. Parikka J (2012) New materialism as media theory: Medianatures and dirty matter. Commun Crit Stud 9:95-100

57. Hornborg A (2014) Technology as fetish: Marx, Latour, and the cultural foundations of capitalism. Theory Cult Soc 31:119-140

58. Noys B (2014) The discreet charm of Bruno Latour. In: Habjan J, Whyte J (eds) (Mis)readings of Marx in continental philosophy. Palgrave Macmillan, London, pp 195-210

59. Flatschart E (2017) Feminist standpoints and critical realism. The contested materiality of difference in intersectionality and new materialism. Journal of Critical Realism 16:284-302

60. Pfeiffer S (2019) From "in the wild" into the wilderness of flied study approaches: The case of the company case study in German industrial sociology in times of digitalization. DiGAP Working Paper 2019; https://www.sabine-pfeiffer.de/files/ downloads/Pfeiffer-2019-Case-Study-diGAP.pdf

61. Foucault M(1991) The Foucault effect: Studies in governmentality. University of Chicago Press, Chicago

62. Bröckling U (2015) The entrepreneurial self: Fabricating a new type of subject. SAGE, London

63. Zuboff $S$ (1988) In the age of the smart machine: The future of work and power. Heinemann Professional, Portsmouth

64. Lyon D (2006) Theorizing surveillance. Routledge, London

65. Souto-Otero M, Beneito-Montagut R (2016) From governing through data to governmentality through data: Artefacts, strategies and the digital turn. Eur Educ Res J 15:14-33

66. Schaupp S (2017) Digital self-evaluation and the cybernetic regime: A sketch for a materialist apparatus analysis. TripleC 1 15:872-886.

67. Galière $S$ (2020) When food-delivery platform workers consent to algorithmic management: A Foucauldian perspective. New Technology, Work and Employment 35:357-370

68. Moore P, Robinson A (2016) The quantified self: What counts in the neoliberal workplace. New Media Soc 18:2774-2792

69. Burawoy M(1979) Manufacturing consent. University of Chicago Press, Chicago

70. Friedman A (1977) Responsible autonomy versus direct control over the labour process. Cap $\mathrm{Cl}$ 1:43-57

71. Edwards R (1979) Contested terrain: The transformation of the workplace in the twentieth century. Basic Books, New York

72. Müller-Jentsch W (1996) Theorien industrieller Beziehungen. Ind Beziehungen Z Für Arb Organ Manag 3:36-64

73. TrinczekR(2018)BetrieblicheRegulierungvonArbeitsbeziehungen. In: Böhle F, Voß GG, Wachtler G (eds) Handbuch Arbeitssoziologie, vol 2. Akteure und Institutionen. Springer, Wiesbaden, pp 579-617

74. Bourdieu P (2010) Distinction: A social critique of the judgement of taste. Routledge, London
75. Anderson E (2017) Private government: How employers rule our lives. Princeton University Press, Princeton Oxford

76. Courpasson D, Vallas S (2016) Resistance studies: A critical introduction. In: Courpasson D, Vallas S (eds) The SAGE Handbook of Resistance. SAGE, London, pp 1-28

77. Hancock AM(2016) Intersectionality: An intellectual history. Oxford University Press

78. Jürgens U (1984) Die Entwicklung von Macht, Herrschaft und Kontrolle im Betrieb als politischer Prozeß: Eine Problemskizze zur Arbeitspolitik. In: Jürgens U, Naschold F (eds) Arbeispolitik. Westdt. Verl, Opladen, pp 58-91

79. Korpi W (1985) Power resources approach vs. action and conflict: On causal and intentional explanations in the study of power. Sociological theory $3: 31-45$

80. Ludwig C, Webster E, Schmalz S (2018) The power resources approach: Developments and challenges. Journal of Social Work in the Global Community 9:113-134

81. Wright EO (2000) Working-class power, capitalist-class interests, and class compromise. Am J Sociol 105:957-1002

82. Danford A (2013) Japanese management techniques and British workers. Routledge, London

83. Delbridge R (1998) Life on the line in contemporary manufacturing: The workplace experience of lean production and the "Japanese" model. Oxford University Press, Oxford

84. Eaton A, Adcroft A, Howes C et al (1995) Lean work: Empowerment and exploitation in the global auto industry. Wayne State University Press, Detroit

85. Milkman R (1997) Farewell to the factory: Auto workers in the late twentieth century. University of California Press, Berkeley

86. Silver BJ (2003) Forces of labor: Workers' movements and globalization since 1870. Cambridge University Press, Cambridge

87. Kotthoff $H$ (2016) Works councils in the mirror of recent research. In: Matiaske W, Artus I, Behrens M et al (eds) Developments in German industrial relations. Cambridge Scholars Publishing, Cambridge, pp 131-156

88. Abelshauser W (2001) Umbruch und Persistenz: Das deutsche Produktionsregime in historischer Perspektive. Gesch Ges 27:503-523

89. BoyerR,DurandJ-P(1997)AfterFordism. Palgrave Macmillan, Basingstoke

90. Gallas A (2018) Class power and union capacities: A research note on the power resources approach. J Soc Work Glob Community 9:348-352

91. Jessop B (1979) Corporatism, parliamentarism and social democracy. In: Schmitter PC, Lehmbruch G (eds) Trends toward corporatist intermediation. SAGE, London, Beverly Hills

92. Panitch L (1981) Trade unions and the capitalist state. New Left Rev 125:21-43

93. Müller-JentschW(1985)Trade unions as intermediary organizations. The Journal of industrial economics 6:3-33

94. Carstensen MB, Schmidt VA (2016) Power through, over and in ideas: Conceptualizing ideational power in discursive institutionalism. J Eur Public Policy 23:318-337

95. KampeterS(2019)Sozialpartnerschaft4.0: Tarifpolitikfürdie Arbeitswelt von morgen. Campus, Frankfurt a.M

96. Frey P, Schaupp S (2020) Futures of digital industry: Technomanagerial or techno-political utopia? Behemoth 13:98-104 
97. Haipeter T (2020) Digitalisation, unions and participation: The German case of 'industry 4.0.' Ind Relat J 51:242-260

98. Meyer U (2018) Digitalisierung ohne Technik? Das Beispiel eines Praxislabors zu Arbeit 4.0. Arb- Ind Stud 11:229-246

99. Müller-Jentsch W (2009) Gewerkschaften als intermediäre Organisationen. VS Verlag fuir Sozialwissenschaften, Wiesbaden

100. Streeck W (1997) German capitalism: Does it exist? Can it survive? New Polit Econ 2:237-256

101. Brinkmann U, Nachtwey O (2017) Postdemokratie und Industrial Citizenship: Erosionsprozesse von Demokratie und Mitbestimmung. Beltz Juventa, Weinheim

102. Harrington J (1973) Computer integrated manufacturing. Industrial Press, New York

103. Coons G (2019) Unpacking reshoring: The GE GeoSpring case. In: Meyer U, Schaupp S, Seibt D (eds) Digitalization in Industries: Between Domination and Emancipation. Palgrave Macmillan, New York, pp 179-203

104. Herrigel G (2015) Globalization and the German industrial production model. J Labour Mark Res 48:133-149

105. Fantasia R, Voss K (2004) Hard work: Remaking the american labor movement. University of California Press, Berkeley

106. Moody K (1997) Towards an international social-movement unionism. New Left Rev I 226:52-72

107. Moody K (2018) High tech, low growth: Robots and the future of work. Hist Mater 26:3-34

108. Stettes O (2016) Digitaler Wandel: Keine Bedrohung für betriebliche Mitbestimmung. Institut der deutschen Wirtschaft (IW), Köln. http://hdl.handle.net/10419/157579

109. Frey CB, Osborne MA (2017) The future of employment: How susceptible are jobs to computerisation? Technological forecasting and social change 114:254-280

110. McAfee A, Brynjolfsson E (2016) Human work in the robotic future: Policy for the age of automation essays. Foreign Aff 95:139-150

111. Acemoglu D, Restrepo P (2018) Artificial intelligence, automation and work. National Bureau of Economic Research. http://www.nber.org/papers/w24196
112. Bolte A, Porschen S (2006) Die Organisation des Informellen: Modelle zur Organisation von Kooperation im Arbeitsalltag. VS Verlag für Sozialwissenschaften, Wiesbaden

113. Green L (2002) Technoculture: From alphabet to cybersex. Allen \& Unwin, Crows Nest

114. Penley C, Ross A (1991) Technoculture. U of Minnesota Press, Minneapolis

115. Robins K, Webster F (1999) Times of the technoculture: From the information society to the virtual life. Psychology Press, London

116. Berg P-O (1985) Techno-culture: The symbolic framing of technology in a Volvo plant. Scand J Manag Stud 1:237-256

117. Ackroyd S, Thompson P (1999) Organizational misbehaviour. Sage, London

118. Jermier JM, Slocum JW, Fry LW, Gaines J (1991) Organizational subcultures in a soft bureaucracy: Resistance behind the myth and facade of an official culture. Organ Sci 2:170-194

119. Fantasia R (1989) Cultures of solidarity: Consciousness, action, and contemporary American workers. University of California Press, Berkeley

120. Mars G (2018) Work place sabotage. Routledge, London

121. Schaupp S (2018) From the "Führer" to the "sextoy". The technopolitics of algorithmic work control. In: SciFive. https://medium. $\mathrm{com} /$ sci-five-university-of-basel/from-the-f\%C3\%BChrer-to-thesextoy-af6b68c634fc. Accessed 26 Nov 2019

Publisher's Note Springer Nature remains neutral with regard to jurisdictional claims in published maps and institutional affiliations. 